
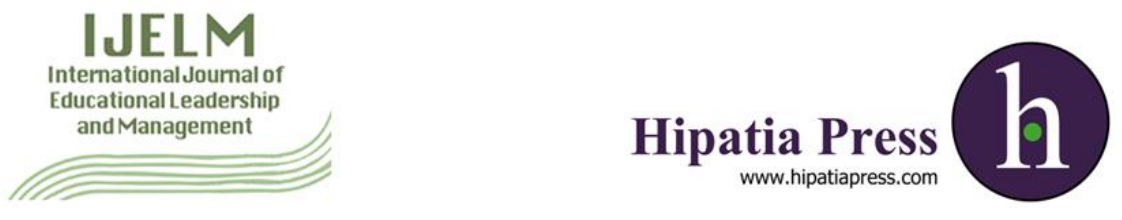

Instructions for authors, subscriptions and further details:

http://ijelm.hipatiapress.com

\title{
Views of Psychosocial and Organizational Dimensions: The Case of Two Elementary School Leaders
}

Liz Barnitz $^{1}$ \& Sharon Conley ${ }^{2}$

1) Hope Elementary School District, California.

2) University of California, Santa Barbara.

Date of publication: January $16^{\text {th }}, 2020$

Edition period: July 2019 - January 2020

To cite this article: Barnitz, L. \& Conley, S. (2020). Views of Psychosocial and Organizational Dimensions: The Case of Two Elementary School Leaders. International Journal of Educational Leadership and Management, 8(1), 2-33. doi: 10.17583/ijelm.2020.4416

To link this article: http://dx.doi.org/10.17583/ijelm.2020.4416

\section{PLEASE SCROLL DOWN FOR ARTICLE}

The terms and conditions of use are related to the Open Journal System and to Creative Commons Attribution License (CCAL). 


\section{Views of Psychosocial and Organizational Dimensions: The Case of Two Elementary School Leaders}

Liz Barnitz

Hope Elementary School District.

California
Sharon Conley

University of California

Santa Barbara

\section{Abstract}

This article used a qualitative interviewing approach to explore psychosocial and organizational dimensions of leadership of two elementary school leaders (principals) in Southern California. At each school, interviews with the school's principal as well as two key informants were conducted, and we analyzed the findings based on principals' mental models, self-efficacy, and immunities to change. Using Kellar and Slayton's (2016) leadership framework, we considered how psychosocial and organizational leadership contexts fostered conditions to promote organizational change. The findings for this study highlight some of the conditions principals believed were important for organizational improvement as well as challenges faced. Findings indicate that psychological and organizational dimensions reveal complexities of educational leadership by providing a fine-grained portrait of leadership and organizational learning. A study implication is that leaders must not only have time for reflection but also be open to identifying their immunities that may deter efforts at growth and change. Research directions are proposed, including further exploration of how leaders' efforts are shaped by their contexts as well as particular challenges experienced in the role.

Keywords: Leadership, Elementary schools, Mental models. 


\section{Visión de las Dimensiones Psicosociales y Organizativas: el Caso de Dos Líderes de Escuelas Primarias}

\author{
Liz Barnitz \\ Hope Elementary School District. \\ California
}

\author{
Sharon Conley \\ University of California \\ Santa Barbara
}

\section{Resumen}

Este artículo utilizó un enfoque cualitativo a través de entrevistas para explorar las dimensiones psicosociales y organizativas del liderazgo de dos líderes (directores) de escuelas de educación primaria en el sur de California. En cada escuela, se llevaron a cabo entrevistas con el director de la escuela, así como con dos informantes clave, y analizamos los hallazgos en función de los modelos mentales, la autoeficacia y las inmunidades de cambio de los directores. Utilizando el marco de liderazgo de Kellar y Slayton (2016), consideramos cómo los contextos de liderazgo psicosocial y organizacional fomentaron las condiciones para promover el cambio organizacional. Los resultados de este estudio resaltan algunas de las condiciones que los directores consideraron importantes para la mejora organizacional, así como los desafíos enfrentados. Los resultados indican que las dimensiones psicológicas y organizativas revelan las complejidades del liderazgo educativo al proporcionar un retrato detallado del liderazgo y el aprendizaje organizacional. Una implicación del estudio es que los líderes no solo deben tener tiempo para reflexionar, sino también estar abiertos a identificar sus inmunidades que pueden disuadir los esfuerzos de crecimiento y cambio. Se proponen instrucciones de investigación, que incluyen una exploración más profunda de cómo los esfuerzos de los líderes están formados por sus contextos, así como los desafíos particulares experimentados en el papel.

Palabras claves: Liderazgo, Escuelas educación primaria, Modelos mentales. 
I

$\mathrm{n}$ the U.S., with its extensive accountability movement, various educational reform efforts have been based on the assumption that strong school leadership can foster school change and improvement, particularly in low or underperforming schools. This assumption is reflected, for instance, in the No Child Left Behind policy initiative in the U.S. that called for changes in leadership as part of its approach to school accountability (U.S. Department of Education, 2002). Although principal leadership has long been seen as critical for leading school change (Blase \& Blase, 1997; Deal \& Peterson, 1994; Drysdale, Goode, \& Gurr, 2011), recent literature has particularly focused on the principal's approach to managing teacher quality (e.g., their recruitment and retention), as well as applying "school leadership principles that leverage whole-school reform" (Kellar \& Slayton, 2016, p. 691).

However, observers (Helsing, Howell, Kegan, \& Lahey, 2008; Kellar \& Slayton, 2016) are increasingly calling on leadership literature to address leaders' own understandings about leadership, improvement goals, and internal psychological conditions that position them to lead effectively. Kellar and Slayton's (2016) review of the existing knowledge base on school leadership indicated that although this literature provides "insight into the effects of leadership on teacher practice and student achievement, it does not help us understand how external school, district, and other factors-as well as internal personal conditions-influence the extent to which a leader is successful in accomplishing what she sets out to accomplish. . . . [That is, it often does not] describe and explain the ways leaders' efforts are shaped by their contexts, their own beliefs, skills, and understandings about leadership, and the subsequent actions they undertake to accomplish their goals" (p. 691).

This observation is consistent with related research. Helsing et al. (2008) suggested that leaders who are attempting to bring about significant school improvement strengthen their articulation and construction of an internal belief system that encourages not only new skill and knowledge acquisition but also their own personal development as leaders. According to Helsing et al. (2008), because current calls for significant change mean that leaders are often "running schools while they are also working to reinvent them," leaders 
who are able to see how their "long-held assumptions limit both understanding and actions" are well positioned to entertain alternative possibilities for reform (pp. 438, 445).

The above perspectives call on research to take up more explicitly the psychological and organizational dimensions of leading people in an organizational context. Within this focus, self-efficacy has been a longstanding area of research (Bandura, 1997; Bandura \& Locke, 2003), with some scholars focusing on leader self-efficacy (Gareis and Tschannen-Moran, 2005; Machida \& Schaubroeck, 2011; Paglis \& Green, 2002). Indeed, Gareis and Tschannen-Moran (2005) argued that central to marshalling an array of skills in exercising leadership is the "principal's own sense of efficacy" (p. 3). They defined leader self-efficacy as "a principal's determination of his or her own effectiveness at a given task or set of tasks, considering his or her own capabilities and experiences, as well as the context in which he or she is working" (p. 3). However, others (Helsing et al., 2008; Kellar \& Slayton, 2016) maintained that a fuller array of other psychological and organizational dimensions should be included in an examination of school leadership. Such a direction would permit more extensive exploration of leadership aspects and "how the leader's professional practice is shaped as a result" (Kellar \& Slayton, 2016, p. 702). These dimensions include mental models and immunities to change that represent an expansion of examination of "psychosocial" aspects and leader attributes that may promote or deter leaders' own growth and efforts at change, particularly among leaders who are new to a school.

In this study, our purpose was to investigate psychosocial and organizational dimensions of leadership in an exploration of two leaders' experiences in Southern California elementary schools. At the time of the study, both schools were implementing school reforms oriented toward an accountability agenda. Both school reforms were encouraged by district directives: one concentrated on science and the other on the development of data use within professional learning communities. A focus on the whole school encompasses school reform implementations at the individual classroom, teacher/instructional team, and school-wide levels. The principals' 
leadership, according to our interviews, suggested potential intersections in psychosocial and organizational dimensions (e.g., self-efficacy), which we were able to explore in relation to how they impeded or promoted their efforts at school change and their development as leaders. The argument we are making is that there is a more nuanced view that considers overlap among not only psychological but also organizational dimensions.

\section{Leadership Framework}

This study adopts Kellar and Slayton's (2016) leadership framework, which presents the extant leadership literature in three primary paradigms. The framework also proposes two leadership dimensions, the psychosocial context and the organizational context. For the organizational context, we draw additional assistance from Collinson and Cook's (2007) organizational learning framework that proposes several conditions of organizational learning.

\section{Leadership Paradigms}

Three primary paradigms have characterized leadership research, with the first emphasizing the qualities and characteristics possessed by leaders. Bolman and Deal (2008) exemplify this paradigm by emphasizing ways in which leaders understand organizational structure, human interrelationships, organizational politics, and symbolism (Brazer \& Bauer, 2013). The second paradigm emphasizes identifying leader behavior by focusing on the contribution of traits to organizational improvement. This aspect emphasizes leaders fostering a culture of inquiry as well as facilitating organizational learning. This work is supported by Collinson and Cook (2007), who emphasized the necessity of inquiry in organizational learning; that is, "the deliberate use of individual, group, and system learning to embed new thinking and practices ... in ways that support shared aims" (p. 8). They suggested that leader strategies that are oppositional to such learning include a reliance on hierarchy and rule-based decision making, which makes organizations less resilient and capable of renewal (Collinson, 2010). 
The third paradigm centers on the leadership role as a way of accomplishing organizational improvement, with a focus on leadership models including instructional leadership, transformational leadership, and distributed leadership. A similar conceptualization of leadership models is offered by Bush (2011), who discusses instructional leadership as including learningcentered leadership, and transformational and distributed leadership as components of a collegial leadership approach.

Kellar and Slayton (2016) make the point that that these various paradigms of thought comprise an initial starting point to understand what leaders do effectively to lead, but may assume that leaders already possess the capacity to facilitate change. To capture further complexity, these authors divide their leadership framework into two aspects of leadership, the psychosocial and the organizational. They state that an important distinction can be made between the "constructs that speak to the psychosocial realm of leadership and those that speak to the organizational learning context of leadership" (p. 696).

\section{Psychosocial Context}

The psychosocial, or psychological, aspect of leadership taps underlying psychological constructs of the leader, including mental models, leader selfefficacy, and immunities to change. Mental models are based on Senge's (2006) work, and can be defined as "systems of evolving thought that govern an individual's observable behaviors and are derived and influenced from one's own context--their experiences, observations, knowledge--and the inherent assumptions the individual forms about the way their world works" (Kellar \& Slayton, 2016, p. 696). Applied to school leadership, mental models are important because inherent assumptions held by a principal are likely to influence the extent to which the leader is able to implement and sustain reforms directed at school change (Kellar \& Slayton, 2016). As Ruff and Shoho's (2005) study of three urban elementary school principals suggested, the "articulation of the mental models of principals, superintendents, and other school leaders provides the capacity to reveal tacit assumptions that have the potential of expanding or limiting organizational capacity" and ultimately student achievement (p. 574). 
As noted, leader self-efficacy is another psychological construct that specifically reflects "leaders' confidence in their abilities, knowledge, and skills in areas needed to lead others effectively" (Machida \& Schaubroeck, 2011, p. 460). High self-efficacy is associated with a process whereby the leader works through challenges to learn from her practice to ultimately achieve "optimal leader development and organizational improvement" (Kellar \& Slayton, 2016, p. 697). A U.S. study of a high school principal, for example, identified the leader to have high self-efficacy in her ability to lead, particularly in the area of instructional improvement (Kellar \& Slayton, 2016).

A third psychological construct relevant to leadership practice involves immunities to change. This concept originated in the work of Helsing et al. (2008), and is defined as the "underlying barriers that prevent an individual from making progress toward a desired professional goal" (p. 441). According to these authors, professional development for leaders should be centered on leader reflection. The immunities to change construct can be helpful to leader professional development by encouraging leaders to reconsider their belief systems. Drawing on the work of Kegan and Lahey (2009), Helsing et al. (2008) suggested that becoming more reflective about belief systems invites leaders to not "hold their fears in a passive way; they also actively (if unconsciously) work to prevent what they are afraid of from occurring" ( $p$. 448). Such fears get in the way of leaders making change in the organization.

A case study of a high school principal, for instance, indicated that the principal espoused a mental model of being an instructional leader, and as such aimed to support teachers in school improvement (Martinez-Kellar, 2012). Among the examples supporting this belief system was a set of materials the principal provided to teachers to improve checking for student understanding. Findings revealed that efficacy was high in this area. However, leader activities associated with the model of instructional leadership was hampered by an immunity to change; in this case, an inability for the leader to reflect and see how her own perspective may impede change. For example, this principal was reluctant to appear as though she were experiencing challenges in her role as principal, which appeared to prevent her from seeking help from others (Martinez-Kellar, 2012). Such examples show how multiple 
psychosocial aspects may interact with one another, thereby providing a more "nuanced [view of educational leadership by investigating] the more organic aspects of leadership and organizational learning” (Kellar \& Slayton, 2016, p. 709).

\section{Organizational Context}

The second aspect of leadership, the organizational context, focuses on organizational learning. Drawing on previous scholarship on organizational learning (Senge, 1990; Slayton \& Mathis, 2010), Kellar and Slayton (2016) asserted that "schools are formal organizations containing social and psychological components whereby teachers and administration construct a sense of efficacy regarding their professional practice and capacity beliefs in an effort to cultivate a professional learning community" (p. 699). Brazer and Bauer (2013) also emphasized acknowledging schools as formal organizational settings in their discussion of leaders' ability to cultivate organizational change and organizational learning. Collinson and Cook (2007) suggested that such cultivation is strengthened by an "inquiry process" that demands as prerequisites (and fosters) "a hospitable attitude toward learning, ... tolerance of new ideas, openness to improvement, and risk taking in the form of willingness to confront mistakes or weaknesses in behavior or thinking" (p. 94). Further, they indicate six conditions that appear necessary for supporting organizational learning within an organization:

- prioritizing learning for all members

- fostering inquiry

- facilitating dissemination of learning

- practicing democratic principles

- attending to human relationships; and

- $\quad$ providing for members' self-fulfillment. (Collinson, 2010, p. 193)

Organizational learning including inquiry processes offer mechanisms for a school to engage collectively in reform and renewal. Given that schools are encouraged to engage in whole school reform involving alterations in instructional and school improvement strategies, like Kellar and Slayton (2016), we felt it would be useful to explore principals' views of the 
psychological and organizational dimensions of leading people in an organizational context. We proceeded to explore these dimensions in our study of principals in two different schools faced with unique organizational improvement challenges, often mandated from outside the school (e.g., at federal and state levels).

\section{Methodology}

The purpose of this study was to investigate psychosocial and organizational dimensions of leadership by exploring two leaders' experiences in Southern California elementary schools. Qualitative interviewing is an appropriate methodology for this study, as it is purposed toward "obtain[ing] descriptions of the life world of the interviewee with respect to interpreting the meaning of the described phenomena" (Kvale, 1996, pp. 5-6). As O'Doherty and Ovando (2013) pointed out, "rather than preconceive participant perceptions, [qualitative interviewing seeks] to engage participants' authentic voices" (p. 536). Furthermore, all types of "qualitative research [are] characterized by the search for meaning and understanding, the researcher as the primary instrument of data collection and analysis, an inductive investigative strategy, and a richly descriptive end product" (Merriam, 2002, p. 6).

\section{Participants}

For this qualitative study, two principals were purposively selected from two Southern California schools on the basis of discussion with district contacts who indicated that each principal was attempting to lead school participants through organizational change at her site. For one principal, there was as an ongoing school relationship with one of the study researchers (the first author, an experienced elementary school principal who holds both teacher and principal certifications) that facilitated researcher access. Pseudonyms were given to retain the privacy and confidentiality of the principal, schools, and personnel. Site A - Leah (a pseudonym), was at Lincoln School (Grades K-6), which served a diverse low socio-economic 
suburban community. Site B - Myra, led Buena Fortuna (Grades K-6), which served a diverse moderate socio-economic suburban community. Regarding school performance, both schools did not meet criteria for Adequate Yearly Progress, or AYP, a federal requirement under the reauthorization of the federal Elementary and Secondary Education Act (ESEA) of 2015, also formerly known as No Child Left Behind (U.S. Department of Education, 2002). This designation assigned each school a Program Improvement status, requiring both to submit school improvement plans (SIPs) based on their adoption of the state's Common Core State Standards (CCSS) as well as district-mandated initiatives. Specifically, one school featured a science instruction initiative and the other had a district professional learning community initiative with built-in release time. Due to the percentage of students considered living in poverty, both schools received federal funding known as Title I. Table 1 summarizes student population, staffing, and years in Program Improvement

Table 1

Selected Characteristics of Study Schools

\begin{tabular}{|l|c|c|}
\hline Characteristics & $\begin{array}{c}\text { School A } \\
\text { Lincoln }\end{array}$ & $\begin{array}{c}\text { School B } \\
\text { Buena } \\
\text { Fortuna }\end{array}$ \\
\hline Grades & K-6 & K-6 \\
\hline Location & Suburban & Suburban \\
\hline No. Teachers (approx.) & 24 & 21 \\
\hline No. Students (approx.) & 435 & 477 \\
\hline $\begin{array}{l}\text { \% Students on free or reduced-price lunches } \\
\text { (poverty indicator) }\end{array}$ & 94 & 57 \\
\hline \% Students English learners & 82 & 49 \\
\hline Principal & Leah & Myra \\
\hline Years in Program Improvement & Year 1 & Year 2 \\
\hline
\end{tabular}




\section{Data Collection}

Data were collected from March 2016 to June 2016. The sources of data included the following. To learn more about each school, its characteristics and reform agenda, we reviewed documents related to each school, such as the school improvement plan (SIP). Also, we reviewed the school's websites. Additionally, the first author conducted two half-day site visits to one school, which entailed her sitting in classrooms, as well as talking to people to get a feel for and understanding of the school environment. A visit to the other school occurred in June after the school year concluded. Although students were not on campus at the second site, the interviews were performed in visits to the administrative office, as well as two classrooms, thereby providing a feel for the school environment (e.g., classroom configurations, classroom displays).

In each school, interviews were conducted with the principal. Selection of two teacher key informants was justified by requiring that they had at least five years of experience within this school. This period was deemed long enough for the teacher to be able to reflect on organizational changes and the leader's practices. In Site A, Leah, Lincoln's school principal, a first-grade teacher, and a fourth-grade teacher were interviewed. In the second Site B, Myra, Buena Fortuna's principal, was interviewed along with a third-grade teacher and a fourth-grade teacher. In the principal interviews, we asked broad questions about the school, leader background, change initiatives, and the principals' approach to problem solving, as well as how they enacted their leadership vision and areas of growth and challenges. To teachers, we asked about their involvement at the school site, how the faculty worked with leadership, strengths of the school including support for teaching and learning, and principal actions that were influential on teachers' practice.

The first author disclosed that she was an experienced teacher and administrator, thereby facilitating rapport with the principal and teacher interviewees. We anticipated that the educator status of the interviewer also facilitated understanding of the nuances in the interview about the challenges that teachers and principals face. Interviews with principals were 
approximately one to one and one-half hours in length, and 45 minutes to one hour for teachers. Audio taped interviews were transcribed in detail for coding and analysis (Kvale \& Brinkmann, 2009; Murphy, 1980; Patton, 2002). The transcriptions allowed the data to be revisited and reviewed in order to retain each participant's perspective (Murphy, 1980) and where possible, transcripts were shared with interviewees.

\section{Data Analysis}

Thematic summaries of views of leadership were written for each participant (principals and teachers) documenting emergent views for each interviewee. In these descriptions, we tried to capture the "subtlety and complexity" of the material by using the respondents' words (Charmaz, 2006, p. 34). We then applied the psychosocial and organizational contexts framework as a method to formulate a conceptual understanding of the principals' mental models, self-efficacy and immunities to change. The theoretical framework for the study was Kellar and Slayton's (2016) leadership constructs; therefore, we drew from this framework to distinguish among the three kinds of psychological constructs (mental models, leader selfefficacy, and immunities to change) as surfaced in the interviews. This typology was helpful in assessing what the leaders were attempting to accomplish as well as potential barriers to leadership development. Further, the theoretical framework was of assistance in coding for leadership constructs. For example, if a principal mentioned providing feedback in a coaching role, the statement was considered related to a mental model of Principal as teacher leader and supporter. In a second example, if the principal mentioned data analysis as a system and teacher evaluation as a system, such statements were considered related to a mental model of Principal as systems leader. Table 2 briefly provides a summary of findings in the three areas of mental models, self-efficacy, and immunities to change. 
Table 2

Mental Models, Self Efficacy and Immunities to Change

\begin{tabular}{|c|c|c|}
\hline & Site A Lincoln & Site B Buena Fortuna \\
\hline 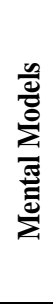 & $\begin{array}{l}\text { The principal primarily endorsed a } \\
\text { mental model of Principal as } \\
\text { instructional leader and secondly } \\
\text { Principal as teacher leader and } \\
\text { supporter. She initiated changes to staff } \\
\text { meetings that would free up time to } \\
\text { share strategies and talk about } \\
\text { instructional issues. }\end{array}$ & $\begin{array}{l}\text { The principal primarily endorsed a } \\
\text { mental model of Principal as systems } \\
\text { leader and secondly Principal collects } \\
\text { and manages data for improving } \\
\text { instruction. She focused on making } \\
\text { data collection and analysis the } \\
\text { cornerstone of school improvement. }\end{array}$ \\
\hline 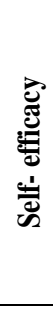 & $\begin{array}{l}\text { The principal felt confident leading the } \\
\text { instructional improvement effort from } \\
\text { her prior teaching roles, having taught } \\
\text { different grade levels and assumed } \\
\text { leader roles. However, self-efficacy } \\
\text { was lower in terms of the realm of } \\
\text { teacher supervision and evaluation. }\end{array}$ & $\begin{array}{l}\text { Prior experience leading a school } \\
\text { improvement plan at a previous } \\
\text { school contributed to a sense of } \\
\text { efficacy. Although she reported low } \\
\text { self-efficacy initially in teacher } \\
\text { evaluation and supervision, } \\
\text { appreciation of differences in teachers } \\
\text { contributed to an improvement. }\end{array}$ \\
\hline : & $\begin{array}{l}\text { The principal's attempts to be a friend } \\
\text { and colleague may have been } \\
\text { problematic when she then attempted to } \\
\text { establish rules. Teachers report that the } \\
\text { principal at times lacked assertiveness, } \\
\text { and the principal appeared to view rules } \\
\text { and assertiveness as being tough. } \\
\text { Principal reported a struggle with } \\
\text { negativity with teachers. An attempt to } \\
\text { be a friend by not giving guidelines on } \\
\text { expectations may reflect an underlying } \\
\text { fear of being seen as having a heavy } \\
\text { hand. }\end{array}$ & $\begin{array}{l}\text { The principal's attempts to focus on } \\
\text { the change initiative concerning data } \\
\text { analysis that resulted in a loss of } \\
\text { teacher collaboration time became } \\
\text { problematic. Less awareness of a } \\
\text { disjuncture between data analysis on } \\
\text { one hand and teacher collaboration } \\
\text { put in place during a previous } \\
\text { administration may have reduced } \\
\text { teachers' reflection on lessons and/or } \\
\text { examination of assessment results } \\
\text { more deeply. }\end{array}$ \\
\hline
\end{tabular}




\section{Limitations}

It is important to acknowledge certain limitations in this research, particularly in relation to the small sample of principals utilized at one level of the school system. A second limitation dealt with data collection occurring at the close of the school year for one site. In one school, key observations of lesson objectives related to data use in classrooms were obtained, whereas in the other observational data were not collected, one of the things Kellar and Slayton (2016) recommend. Third, as O'Doherty and Ovando (2013) suggested, it is important to provide confirming or disconfirming evidence of principals' views from teachers and district leaders. Although we did incorporate teachers for this possible evidence, district leaders were not included. A fourth limitation is that the study did not utilize an immunities to change-professional development component, which would require a longer time frame to reflect on changes (Helsing et al., 2008). That is, leaders were not actually asked to reflect on their immunities as Helsing et al. (2008) recommend; instead, immunities to change were inferred from principal and teacher descriptions. It is hoped, however, that interviews in this study are revealing about underlying challenges that appeared to suggest some immunities to change. Finally, by adopting Kellar and Slayton's (2016) framework, other salient themes may have been missed. However, as we present the findings, we hope to show the nuanced intersection of the psychological and organizational realms in the study framework.

\section{Results}

Findings of this study are presented for each principal beginning with the principal's background and focus of change at each school, followed by mental models, self-efficacy, and immunities with particular reference to their roles to facilitate organizational improvement. We highlight the conditions principals believed were important for organizational improvement and challenges faced. Further, our references to school leadership in these findings draw not only from the principals' accounts but also from teacher informants within each of the schools. 


\section{Leah}

Background and Organizational Improvement Focus

Leah's work as principal at Lincoln began when she was hired in 2013 from a teaching position at another elementary school within the district. Upon coming to the school, Leah described a "wonderful" school community coupled with an "amazing" group of teachers who were "ready to learn new things." Teachers, as she described, were "young [but] very committed to students." According to one teacher, the faculty was comprised of "life-long learners" who enthusiastically embraced school change initiatives.

As a school in Program Improvement, Lincoln was mandated by the state to develop a formal school improvement plan (SIP) (previously introduced), which became a focus of Leah's initial effort as principal. The SIP included the implementation of the state's CCSS and other districtmandated initiatives. One of these initiatives was for the school to become the district's first science, technology, engineering, and math (STEM) pilot school. Science was further identified as the instructional entry point, meaning that (a) professional development in science would be provided for the school's teachers by outside experts and (b) science instruction would be integrated on a daily basis across grades. Leah characterized both of these as constituting a "huge [and] big change" for the school. She described how the school got started.

So [the teachers and I] sat down as a staff and we said, "We're going to push math and science." We did a whole visionary thing. We envisioned and then put together an action plan. We said, "This is where we are, and this is where we're going to be in the first year, and this is where we'll be in the second year." 
According to one teacher, "With the new science pilot, our staff really stepped up their game, rolled up their sleeves and jumped in." According to another, the staff was "very cohesive and had a lot of energy and enthusiasm about science."

During this work, Leah attempted to convey the idea that it was all right to expect and make mistakes. "I told the teachers that this first year you can muck around with [math and science]. I won't be evaluating you on science [instruction] because I want you to muck around. It's going to be messy. But I want you to do it, commit to it, knowing that it's not going be perfect. And I want you to say to yourself, 'I'm hanging in there.' And then you talk about it with [your colleagues], reflect on it, and then you change." She added that to "expect mistakes, and . . . learn from those mistakes" was part of a school improvement process, which appears similar to the inquiry process described by Collinson and Cook (2007). Leah said, "[To me that's] a way to bring [about] changes, by having that freedom-by giving yourself a chance to make mistakes and then say, 'OK I can do it better. "'

Although the emphasis on science was seen by everyone as beneficial, it meant that teachers would be out of their classrooms frequently to attend professional development sessions. According to Leah, time was scarce in the school, made even more challenging with the entry of a new cohort of seven teachers (approximately 30 percent of the staff). This influx exacerbated the time crunch dilemma by adding the need to coach and socialize teachers who were new to the school and profession. As she said, "As a new teacher, you can have all sorts of great ideas but until you've done it a while, you make mistakes. New teachers require a lot of coaching, and that takes time.'

\section{Mental Models}

In discussing her leadership, Leah primarily endorsed a mental model Principal as instructional leader and secondly Principal as teacher leader and supporter. Throughout her interview, Leah often stressed her role as instructional leader, at times differentiating it from and emphasizing it over 
that of "manager." As instructional leader she said she focused on maximizing time for instruction by, for example, initiating a change to staff meetings. She distributed weekly letters with any business items that needed to be addressed in advance, thus freeing up time during the meeting to "share engagement and strategies and talk about instructional issues."

Second, she endorsed a mental model of Principal as teacher leader and supporter in her discussion of (a) her changes to the master schedule that helped support teachers and (b) her preferred role as teacher coach and collaborator. Regarding schedule changes, Leah placed time for teacher planning and teacher collaboration as a central focus, working with the schedule to create extra time for teachers to "plan and learn the new science curriculum." According to one teacher, Leah had also "refined the schedule" to better accommodate teacher collaboration, continuing a consistent emphasis on planning time put in place by a previous (well-regarded) administration.

Also within the second model, Leah described herself as a coach who wanted "people to succeed." In the words of one teacher, Leah was "collaborative. [She would] bounce ideas off me instead of just ask for input or provide feedback." The teacher also described Leah as "highly supportive of the on-site professional development [because she could] see the value of it," thus reinforcing the teacher-as-supporter model.

Self-efficacy

Leah's tenure as principal was marked by a sense of confidence from her prior teaching roles but also trepidation about the uncertainty of the position. In her 26 years of teaching, she had taught "lots of different grade levels" and assumed numerous teacher "leadership roles" making her feel generally wellprepared to take the helm. As Principal as teacher leader and supporter and Principal as instructional leader, she felt efficacious in these areas, in being able to discuss with teachers ways for them to collaborate and grow their knowledge of science curriculum. She mentioned her oversight of 
instructional programs and personnel throughout her interview, and particularly science as an emphasis since she had taken over the school, a focus which she was expected to continue to energize through supporting professional development. Her comments about leading the instructional improvement effort reflected her high sense of efficacy in the position overall.

However, she expressed a lower level of leader self-efficacy in terms of the realm of teacher supervision and evaluation. She described teacher evaluation as "hard," preferring to be a coach (aligning with her mental model as teacher leader/supporter) as opposed to an evaluator. Possibly consistent with this view, one teacher interviewee said that, as supervisor, Leah was perhaps not "in the classroom enough," stating that as "administrator you need to know what's going on, to ask yourself, 'Is the instruction in this classroom consistent with what we've outlined as [school goals]?'".

The other area in which Leah felt less than efficacious was her ability to deal with the uncertainty of the position. She described her first year as "good" but also "a lot to take on," even recalling feeling "just numb." She attributed this feeling to the several district-mandated initiatives (e.g., science and math, professional development), and having many first-year teachers at the school. Yet she said everyday "uncertainty" that accompanies the position did not diminish her fondness for the work: "Every day you never know what's going to hit you. I was exhausted [yet also] absolutely loved it."

\section{Immunities to Change}

Interview comments also suggested a possible immunity to change. According to one teacher, "When [Leah] first came [to the school], she tried to be so kind and [a friend to everyone]. Then she tried to establish rules. [The staff] weren't willing to accept her authority. She didn't have [that] assertiveness." But the teacher added "I don't think we did enough to work together to support Leah." 
Leah may have been unaware that her attempts to be a friend and colleague initially might have created a backlash when she then attempted to establish rules. The possibility that her efforts to be collaborative partner to teachers might have created an immunity to change is one suggested by Leah herself.

"I have a hard time with the negativity, and so when it gets to the point where I feel like my job becomes a negative, I don't like it. This job takes being tough, too, and I might not be tough enough. I'm tough in a lot of ways: I'm smart, and I can problem solve, but I may not be tough enough. That's probably the biggest struggle."

The atmosphere of imposing rules on adults may be oppositional to the conditions for organizational learning (previously described), thus contributing to a struggle with "negativity" with teachers. Specifically, the principle of human relationships may be at play when rules are imposed on adults without involving them (Collinson \& Cook, 2007). A lack of awareness of a balance point between providing rules and collaboration with teachers may have prevented Leah from creating the human relationships one has to have for the position. Perhaps her desire to appear to be a friend reflected an underlying fear of being seen as having a heavy hand, eventually creating a struggle with negativity with the teachers. Enhancing a sense of "collaboration" and "trust" in the principalship results from principals acting consistently as both collaborators and proponents of a shared governance approach (Collinson, 2013, p. 184).

\section{Myra}

Background and Organizational Improvement Focus

Myra came to her position at Buena Fortuna having taught for 15 years, in positions that ranged from 7 th grade English to Kindergarten. She was hired in 2013 from a position as principal designee at another of the district's elementary schools. At Buena Fortuna, Myra described the school's teachers as "hard workers" who were "learners themselves." Further, she characterized the parents in the community as hardworking and supportive, providing the example of parents who would take two buses to the nearest supermarket to 
purchase family groceries. The school had strong outreach to the community as well, with "a wonderful school psychologist and after-school program director... establishing a strong connection where parents know they can go if they need something."

Teachers reinforced the view of a diligent and caring staff. As one said, teachers were "not afraid of hard work [and] cared about the [student] population, want[ing] our kids to succeed." She attributed a high level of collaboration and "unity" in part to a previous administration who had "pulled the staff together" in a time of crisis when the school had initially received Program Improvement status. (The school had previously received the designation, and for the second time during Myra's tenure.) The teachers' unity and shared vision was perhaps reflected when Myra said teachers were "critical thinkers [who] don't just accept everything I say." According to the teacher,

"Myra came into this ship that was on a good trajectory. We felt good about what we were doing. So, a lot of what she did, in my opinion correctly, was just to let status quo maintain status quo. We were doing the right things. Myra had her own input by having us look at the data a little more closely, at what we could be doing differently."

During Myra's tenure, Buena Fortuna's SIP featured two major change components, the first, to implement district- and state-mandated CCSS, and the second to implement a district directive to improve the collection and analysis of data, informing instruction within school professional learning communities. Myra felt comfortable leading the second component in particular, having developed a school improvement plan involving data analysis and interpretation at a previous school. She described her approach at Buena Fortuna.

"I'm [currently] doing facilitated leadership around data analysis as well as the logistical management of the data. Next year I have plans to share this capacity [with teachers]. But I think we've come a long way this year looking 
at data, because I was able to manipulate it myself and figure it out. I wouldn't have been able to get us where we are if I had left this [solely] to the teachers. I wanted to ease the burden for teachers this year. Next year, I want teachers to be able to analyze their own data."

This two-year process would be valuable in her view, because the school could track student progress and make adjustments accordingly.

"Our [student achievement] data shows that if we keep doing the same thing, getting the same results, then we would have about $60 \%$ of students on grade level, which is great for $60 \%$ of our kids. But we still have $40 \%$ who wouldn't be [on grade level]. So if we want to lessen the percent [age of students] who aren't on grade level, and increase the percentage ... who are, then we have to do something different."

According to one teacher, during Myra's tenure, the staff had "looked at data more with her than any other principal" and that this experience was ultimately valuable.

"I hate to make [Myra] to sound like she's all about the numbers, but I really feel that this is the focus she has. It's a gift that she has given to us, [in] that you can really feel good about the decisions you're making when you feel like you have some data to support those decisions."

According to the other, "one of the biggest new focuses brought about by [Myra] was focusing on data, making sure we're using various assessments to record student growth, and then putting it all together to get a clear picture of how we're doing. Since we work well together as teachers and communicate a lot, this is a really good practice if we need to improve academically." 


\section{Mental Models}

Myra primarily endorsed a mental model of Principal as systems leader and secondly Principal collects and manages data for improving instruction. Regarding the first, she referred to creating and maintaining effective systems when discussing data use, student discipline, creating and maintaining a positive school climate, and teacher supervision and evaluation. For instance, she described supervision and evaluation as a system of "layers" of observation, feedback, and support. Also prominent in her mental model of Principal as systems leader was her role in making data collection and analysis the cornerstone of organizational improvement. Within this model, data collection and analysis was seen as a system in itself, creating the conditions to positively affect instructional changes that would in turn bring about improved student achievement. As she said, she is a "big picture person." She described her previous roles as teacher leader as involving "behind the scenes organizational stuff such as writing staff agendas." To her, this exercise felt like something that was a good fit for her big-picture thinking and her strength in organizing.

Indeed, the related mental model of Principal collects and manages data for improving instruction was an important stand-alone model for Myra. She referred to having introduced a culture of data analysis to the faculty, of creating a system of managing data that would facilitate easier access for teachers in analyzing the data, and of identifying her and teachers' work with data as the single most important factor in bringing about organizational change. In addition, this mental model appeared evident in school practice according to both teacher interviewees, who described one of Myra's more effective roles at the school as her focus on student assessment data to bring about changes in instruction. For example, a site visit revealed classroom data visibly displayed and student learning goals posted. One teacher was observed explaining to her students that the lesson objective was directly related to students' results on a particular assessment, revealing an area of difficulty for the majority of them. This example suggested that Myra's belief system, Principal collects and manages data for improving instruction, was enacted instructionally, creating the change she envisioned for her teachers. 
Self-efficacy

When examining the relationship between Myra's leader self-efficacy and her mental models-Principal as systems leader and Principal collects and manages data for improving instruction-Myra appeared to have a high level of self-efficacy in these areas. For example, her experience leading a school improvement plan at a previous school involving extensive analysis and interpretation of data (previously described) appeared to contribute to her high sense of efficacy.

Myra reported low self-efficacy initially in the area of teacher evaluation and supervision. In describing her overall philosophy, she explained that her priority in this area was to build a "level of relationship between administration and the teachers that you're working with." She felt more confident to supervise and evaluate teachers in her second year as opposed to her first year as principal, because, as she explained, it took time to "know the teachers and what makes them tick and what their personal needs are." She spent some time in the interview describing the differences between new and veteran teachers, suggesting, for example, that "a 20-year veteran may not see that the [teaching] career has changed, and I have to be clear with them about what the new expectations and demands are." For new teachers, "they have the potential but not the knowledge, so it's connecting them with resources and helping them build relationships with their partners." Appreciation of these differences by the second year of her tenure arguably translated to feelings of higher self-efficacy.

\section{Immunities to Change}

A possible immunity to change focused on the relationship between Myra's change initiative concerning data analysis on one hand and teacher collaboration put in place during the previous administration on the other. When asked how the teaching staff worked to solve problems that were influential on practice, one teacher said that during Myra's first year as principal, even after refining the schedule, there was a loss of teacher 
collaboration time. Established under the previous administration, collaboration time was seen by both of the teachers interviewed as a key element in effective planning and communication within grade-level teams. One teacher believed a reduction in time allocated to teams diminished her own ability to "plan or reflect on lessons or look at assessment results more deeply." Further, as a second teacher explained, time allocated within Myra's administration to focus on the goals of data analysis was initially met with teacher resistance.

Thus, there was a suggestion by teacher interviewees that teachers were already collaborating. With the new data analysis initiative, the interviewees expressed they could not continue their previous practice; that is, they had to stop what they were doing successfully before. Although Myra reported some awareness of this condition (and furthered a teacher survey addressing collaboration), she stopped short of recognizing the close tie of collaboration to the mandated professional learning communities effort. While appreciating the new focus on data--"making sure we're using various assessments to record student growth, and then putting it all together to get a clear picture of how we're doing"--teachers expressed concern about the collaborative work the initiative was cutting into. Teachers may have been ahead of the principal in a way, with Myra perhaps unaware that this disjuncture was creating a lack of shared understanding about collaboration as a priority already established. According to one teacher, "shared leadership" was a "resource" she felt was underutilized at the school, perhaps contributing to lack of shared understanding, a condition for organizational learning (Collinson and Cook, 2007). As Printy, Marks, and Bowers (2009) suggested, shared leadership is important in "acknowledg[ing] the critical contributions of both principals and teachers to the central activities of schooling: curriculum, instruction, and assessment" (p. 508). 


\section{Discussion and Conclusions}

Kellar and Slayton's (2016) framework was chosen for this study because it expands the focus of leadership researchers beyond single constructs, such as self-efficacy, to encourage examination of multiple constructs. These constructs include mental models, self-efficacy, and immunities to change. In addition, they call on researchers' investigations to include interviews with teachers and administrators and classroom observations to identify and explore these constructs. "This framework offers a launchpad to consider how these elements interact and intersect with one another. This framework also illustrates our argument that leadership is not influenced by one element or ideas but an amalgamation of constructs that, through their interactions and intersections, influence a leader's efforts in achieving the very change she is setting out to achieve" (p. 707).

These authors' prior research using case study methods, for instance, demonstrated one principal's mental model of instructional leadership and sense of efficacy based on previous career successes, as well as immunities to change. One immunity revealed a preoccupation with not appearing to fail, in turn hampering the leader's efforts to encourage the risk taking needed for experimentation underway at the site.

We adopted this stance of exploring multiple constructs in the current study. Our exploration of elementary school principals, both in their second year as principal, revealed leaders who felt efficacious based on many years of teaching experience, teacher leader positions, and (in one case) principal designee. The principals' mental models differed, however, with one focused primarily on instructional leadership and the other on adopting a systems approach and data leader model. In both cases, the leaders' mental models aligned with the organizational improvement effort underway at the site. At one site, an instructional initiative focused on science was ongoing and at the other, there was a professional learning community promoting teacher data analysis within teams. However, in one case, the leader (Leah) appeared to lack awareness that attempting to be a friend and colleague initially might create a backlash of negativity when she then attempted to become more 
authoritative. This negativity, as Leah expressed, was "hard to handle" and at odds with her overall effort to have a collegial relationship with teachers. For the other leader, Myra's efforts to enact changes to increase the data capacity on site aligned with her mental model and district priorities but she appeared less aware of how the approach might be undercutting previously established team collaborative practices. Further, both principals expressed somewhat low self efficacy in the realm of teacher evaluation and supervision. For one principal, a mental model that stressed collaboration and coaching appeared not to accommodate teacher evaluation well, thus also demonstrating an interaction among different leadership constructs.

For practice, Kellar and Slayton (2016) advocated principals being more self-aware of their mental models, self efficacy, and potential immunities to change. Additionally, principals must be open to soliciting feedback that may result in overcoming these immunities. Previous scholarship suggests that norms against advice seeking and advice taking often characterize socialization to the teaching profession (Little, 1990; Smylie, 1992). For instance, some teachers are "cautious about exposing their difficulties or accomplishments" (Little, 1982, p. 335). It is perhaps not surprising that when progressing to the principalship, these norms may persist with occupants reluctant to seek out feedback that may potentially address obstacles to change. Leah, for example, may have displayed this reluctance in stating that she had a "hard time" with negativity. Feedback often includes negativity and openness to feedback may include the possibility of openness to negativity as well.

That is, the framework utilized in this study draws attention to not only whether leaders have time for reflection but also whether they are open to identifying their immunities to change and altering their own personal beliefs that might get in the way of change. Ugur and Koc (2019), in a study of leaders' views of technology, indicated that administrators interviewed had strong beliefs that technology should be implemented. Juxtaposed with the current framework, questions may be raised about the possibility of such principals being transparent about their belief systems (e.g., technology, data analysis within teams) with others in the school, and additionally being open 
to how one's belief system might prevent one from seeing others' perspectives and validating those other perspectives. This observation speaks to the intersection between mental models, self-efficacy, and immunities to change. A strong belief system may encourage them to feel good about their skills in these areas, but they must also be open to identifying immunities to change by engaging in self-reflection (Kellar \& Slayton, 2016).

Principal reflection was evident in the present study when, for example, Myra reflected on her second year as having more of an appreciation of differences in teachers. Myra reported being aware of a loss of collaboration and pointed to developing a survey to gather information on teacher collaboration. However, although she was able to articulate differences in teachers, teachers still reported feeling impeded in their previous collaborative work. This finding may correspond to the principle of "attending to human relationships" within organizational learning theory, which affirms that organizational learning and school improvement "depends on the social system in which human beings interact to construct their learning and learn from each other" (Collinson \& Cook, 2007, p. 149).

In this context, further attention might be provided on how immunities to change may relate to conditions for organizational learning as outlined by organizational learning scholars. Collinson and Cook (2007) emphasized how open the leader must be to feedback in advocating an "inquiry process," presumably not only within the school but perhaps also among one's peer group of principals. Within schools, the potential for teacher inquiry and opening a two-way channel of communication for feedback may have been hampered by the external mandate for change that was present in both schools. Further, among peer groups of principals, according to Bengston, Zepeda, and Parylo (2013), "new principals value peer involvement in the socialization process" (p. 147). However, others (Printy et al., 2009) observed that "school districts generally fail to provide adequate technical assistance, such as coaches, to fledgling principals" (p. 508). This observation raises the question as to whether there exists sufficient support for inquiry processes and mentoring for principals (Crow, 2006; Printy et al., 2009). In order for inquiry processes to happen within the school, principals arguably need to inquire 
within themselves as to what their immunities to change are, perhaps aided by peer feedback (Kellar \& Slayton, 2016).

There are several limitations of the current study that suggest directions for further research. First, future studies might utilize a longer time frame of interviewing at the site. For instance, a second round of interviews with focused questions might be utilized to flesh out potential immunities to change emerging in initial data collection. It would also be interesting to revisit these principals and the same teachers in a year to see if they have changed their perceptions. As noted earlier, a longer time frame for the study may have also shown shifts in principal self-awareness, and then new practices may have emerged over time. However, it is hoped that our analysis is a starting point to help leaders recognize the importance of possible immunities to change in their leadership practice. Second, additional psychological dimensions might be explored. More could have been done to discover what was stressful about the experience, and thus stress, and even trauma, could be explored in studies of teachers moving to a new leadership position as Daresh (1986) indicated. Recognizing that leaders can adopt self-protective stances, the immunities to change construct invites people to understand that they need not hold their fears in a passive way, as noted earlier (Helsing et al., 2008). That is, fears from a trauma need not be held inside; when they are, fears from a trauma can influence leadership (Helsing et al., 2008). In this study, Leah struggled with a new position of authority, preferring her role as coach and friend, to supervisor and evaluator. Such tensions and reservations may be enhanced in an accountability environment where accountability for student and school performance have been characterized as a "universal challenge" facing principals (Bengston et al., 2013, p. 145). Useful research directions include the interpersonal challenges facing principals including handling conflict, anxiety over evaluating teachers, lack of feedback and assistance in the position, and underlying fears associated with the position.

\section{Acknowledgments}

The authors acknowledge the very helpful assistance of Jacquelyn Kemp and Christopher Ozuna on previous versions of this manuscript. However, any errors or omissions are our own. 


\section{References}

Bandura, A. (1997). Self-efficacy: The exercise of control. New York, NY: W. H. Freeman.

Bandura, A., \& Locke, E. A. (2003). Negative self-efficacy and goal effects revisited. Journal of Applied Psychology, 88(1), 87-99.

Bengston, E., Zepeda, S. J., \& Parylo, O. (2013). School systems' practices of controlling socialization during principal succession: Looking through the lens of an organizational socialization theory. Educational Management Administration \& Leadership, 41(2), 143-164.

Blase, J., \& Blase, J. (1997). The fire is back! Principals sharing governance. Thousand Oaks, CA: Sage.

Bolman, L. G., \& Deal, T. E. (2008). Reframing organizations: Artistry, choice, and leadership (4th ed.). San Francisco, CA: Jossey-Bass.

Brazer, S. D., \& Bauer, S. C. (2013). Preparing instructional leaders: A model. Educational Administration Quarterly, 49(4), 645-684.

Bush, T. (2011). Theories of educational leadership and management (4th ed.). London: Sage.

Charmaz, K. (2006). Constructing grounded theory: A practical guide through qualitative analysis. London: Sage.

Collinson, V. (2010). To learn or not to learn: A potential organizational learning gap among school systems? Leadership and Policy in Schools, 9(2), 190-219.

Collinson, V. (2013). Teacher-principal collaboration: Partnerships or power plays? In S. Conley \& B. S. Cooper (Eds.), Moving from teacher isolation to collaboration: Enhancing professionalism and school quality (pp. 183-201). Lanham, MD: Rowman \& Littlefield.

Collinson, V., \& Cook, T. F. (2007). Organizational learning: Improving learning, teaching, and leading in school systems. Thousand Oaks, CA: Sage. 
Crow, G. M. (2006). Complexity and the beginning principal in the United States: Perspectives on socialization. Journal of Educational Administration, 44(4), 310-325.

Daresh, J. C. (1986). Support for beginning principals: First hurdles are highest. Theory into Practice, 25(3), 168-173.

Deal, T. E., \& Peterson, K. D. (1994). The leadership paradox: Balancing logic and artistry in schools. San Francisco: Jossey Bass.

Drysdale, L., Goode, H., \& Gurr, D. (2011). Sustaining school and leadership success in two Australian schools. In L. Moos, O. Johansson, \& C. Day (Eds.), How school principals sustain success over time: International perspectives. (pp. 15-38). Dordrecht: Springer.

Gareis, C. R., \& Tschannen-Moran, M. (2005). Cultivating principals'sense of efficacy: Supports that matter. Paper presented at the annual meeting of the University Council for Educational Administration, Nashville, TN.

Helsing, D., Howell, A., Kegan, R., \& Lahey, L. (2008). Putting the "development" in professional development: Understanding and overturning educational leaders' immunities to change. Harvard Educational Review, 78(3), 437-465.

Kellar, F., \& Slayton, J. (2016). Fostering and achieving organizational change: A framework for studying the complexities of school leadership. Journal of School Leadership, 26(4), 690-715.

Kegan, R., \& Lahey, L. L. (2009). Immunity to change: How to overcome it and unlock potential in yourself and your organization. Boston: Harvard Business Press.

Kvale, S. (1996). Interviews: An introduction to qualitative research interviewing. Thousand Oaks, CA: Sage.

Kvale, S., \& Brinkmann, S. (2009). Interviews: Learning the craft of qualitative research interviewing. London: Sage.

Little, J.W. (1982). Norms of collegiality and experimentation: Workplace conditions of school success. American Educational Research Journal, 19(3), 325-340. 
Little, J.W. (1990). The persistence of privacy: Autonomy and initiative in teachers' professional relations. Teachers College Record, 91(4), 509536.

Machida, M., \& Schaubroeck, J. (2011). The role of self-efficacy beliefs in leader development. Journal of Leadership and Organizational Studies, 18(4), 459-468.

Martinez-Kellar, F. J. (2012). A tale of two principals: The complexity of fostering and achieving organizational improvement. Unpublished doctoral dissertation, University of Southern California, Los Angeles, CA.

Merriam, S. B. (2002). Qualitative research in practice: Examples for discussion and analysis. San Francisco: Jossey Bass.

Murphy, J. T. (1980). Getting the facts: A fieldwork guide for evaluators and policy analysts. Glenview, IL: Scott Foresman.

O’Doherty, A., \& Ovando, M. N. (2013). Leading learning: First-year principals' reflections on instructional leadership. Journal of School Leadership 23(3), 533-561.

Paglis, L.L., \& Green, S. G. (2002). Leadership self efficacy and managers' motivation for leading change. Journal of Organizational Behavior, 23(2), 215-235.

Patton, M. (2002). Qualitative research and evaluation methods ( $3^{\text {rd }}$ edition). Thousand Oaks, Sage.

Printy, S.M., Marks, H. M., \& Bowers, A. J. (2009). Integrated leadership: How principals and teachers share transformational and instructional influence. Journal of School Leadership, 19(5), 504-532.

Ruff, W. G., \& Shoho, A. R. (2005). Understanding instructional leadership through the mental models of three elementary school principals. Educational Administration Quarterly, 41(3), 554-577.

Senge, P. M. (2006). The fifth discipline: The art and practice of the learning organization. New York, NY: Doubleday. 
Slayton, J., \& Mathis, J. (2010). Building the leaders we need: The role of presence, learning conditions, and andragogy in developing leaders who can change the face of public Pre-K through 12 education. In A. H. Normore (Ed.), Global perspectives on educational leadership reform: The development and preparation of leaders of learning and learners of leadership (pp. 23-45). United Kingdom: Emerald Group.

Smylie, M. A. (1992). Teachers' reports of their interactions with teacher leaders concerning classroom instruction. The Elementary School Journal, 93(1), 85-98.

Ugur, N. G., \& Koc, T. (2019). Leading and teaching with technology: School principals' perspective. International Journal of Educational Leadership and Management, 7(1), 42-71.

U.S. Department of Education (2002). No Child Left Behind. Washington DC: Author.

Liz Barnitz is Principal of Hope Elementary School in Hope Elementary School District. She received her $\mathrm{PhD}$ in education from University of California, Santa Barbara. Liz has more than twenty years of experience as an educator, serving as a teacher, a site administrator and a district administrator. Her interests are in the areas of instructional leadership and teacher supervision.

Contact Address: 3970-A La Colina Rd, Santa Barbara, CA 93110 E-mail: lizbarnitz@gmail.com

Sharon Conley is Professor in the Department of Education at University of California, Santa Barbara. She received her $\mathrm{PhD}$ in education from the University of Michigan. She has authored publications in the areas of organizational behavior and theory in schools, educational reform, and the managerial work environments of teachers.

Contact Address: Department of Education, UC Santa Barbara, Santa Barbara, CA 93106-9490

E-mail: sconley@education.ucsb.edu 